
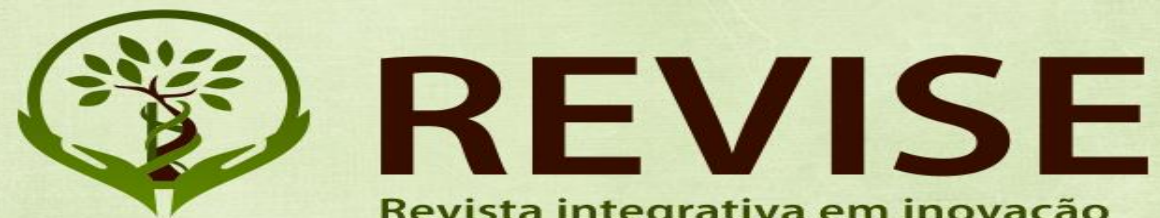

Revista integrativa em inovação tecnológica nas ciências da saúde

ISSN: $2179-6572$

\title{
O SAGRADO QUE CURA: PRÁTICAS DE SAÚDE DENTRO DAS CASAS DE SANTO
}

Leticia Gambelegé Silva Secretaria de Cultura SAJ

\section{RESUMO}

O artigo registra as conferências do evento congresso internacional de inovação tecnológica nas ciências da saúde: a sustentabilidade das práticas integrativas a agroecologia, mais especificamente a conferência $O$ Sagrado Que Cura: Práticas De Saúde Dentro Das Casas De Santo. O evento aconteceu de 15 a 18 de novembro de 2017 no IFBA SAJ sob a direção da Universidade Federal do Recôncavo da Bahia.

Palavras-chave: Ancestralidade. O tempo. Ervas aromáticas. Proteção nas relações humanas.

\section{ABSTRACT}

The article records the conferences of the event international congress on technological innovation in health sciences: the sustainability of integrative practices in agroecology, more specifically the conference The Sacred Healing: Health Practices Inside the Casa De Holy. The event took place from November 15 to 18, 2017 at IFBA SAJ under the direction of the Federal University of Recôncavo da Bahia.

Keywords: Ancestry. The time. Herbs. Protection in human relations. 
Silva, L. G. (2018).
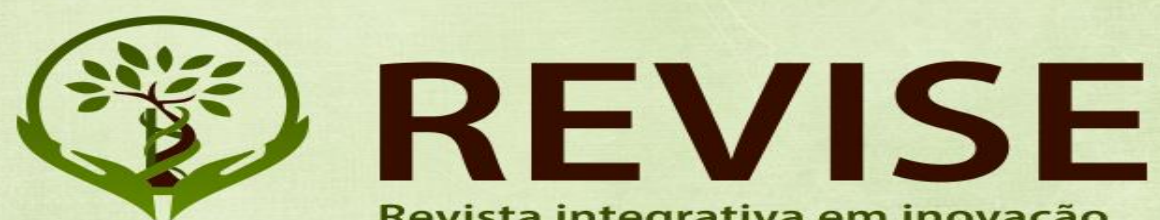

Revista integrativa em inovação tecnológica nas ciências da saúde

ISSN: $2179-6572$

\section{CONFERÊNCIA}

A fala é um espaço de poder determinante, por isso peço licença para falar. A fala é acerca da minha casa, de Ossaim, orixá que detém o conhecimento das folhas, o médico do Candomblé. Nação Angola é Cadedê. Para nós, nada é lixo, pois tudo tirado da natureza deve ser retornado a ela. Ossaim é o Orixá que toma conta das raízes, chás e sementes. Sem folha não tem vida, sem folha não tem Orixá. O tempo é fundamental, principalmente nas práticas de cura, afinal, um mal de anos não é para ser curado em minutos. A ansiedade é a oportunidade para acalmar e esperar o momento em uma casa de religião de matriz africana. Nossas práticas de cura são baseadas na exposição de curas. Os banhos e chás podem triplicar uma dor de cabeça. Uma colher de açúcar assanha os vermes para que os purgantes a base de folhas e ervas possa matar os vermes. A cura é com base no Axé. Por isso o tempo é decisivo nas práticas de cura no Candomblé. O Sagrado traz a cura. Quando se entra em contato com o sagrado em prostração as aflições e tristezas são ali deixadas. Andamos descalços porque precisamos estar em contato com a terra, com tudo aquilo que nos deixa em pé. Na prática curativa há o contato corporal, muito evitado hoje em dia. Dormimos cedo, tomamos banho de água fria e usamos ervas para estar em contato com a natureza e fazermos nossas práticas curativas. $\mathrm{O}$ banho da aroeira, triturada em pilão preferencialmente de madeira por causa do aumento da temperatura, pode acalmar. Talos da mamona são usados na cerimônia da sasanha, mas é segredo para os religiosos. 
Silva, L. G. (2018).
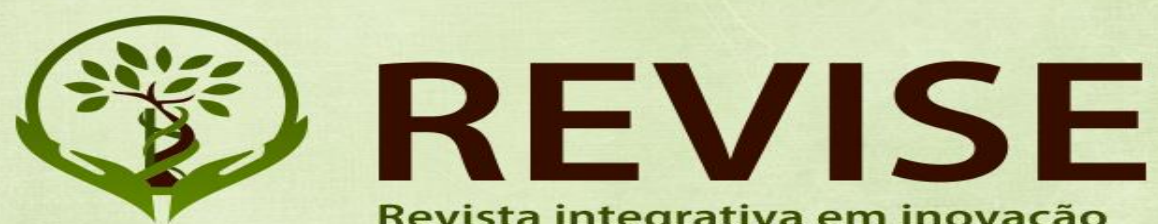

Revista integrativa em inovação tecnológica nas ciências da saúde

ISSN: $2179-6572$

Esse talo, seco e amarrado permite a feitura de cestos fortíssimos, mas depende da aceitação tempo. O sacrifício de animais não é a abominação que é colocada. O sangue é ofertado diretamente no chão. As vísceras são devolvidas para a natureza, para as águas da mata, para voltar à terra. Algumas senhoras do Axé, com paciência enorme usam pau de vira tripa, para lavar e comer. Alguns que falam "que nojo", mas comem sarapatel e dobradinha. Tudo nosso é feito no barro, pois este se desmancha com o tempo e retorna à natureza. Práticas que usam metal ou plástico são más práticas religiosas. Sem água nada tem vida. Iemanjá e Oxum estão ligadas a água. Útero seco é ausência de umidade, água. Para acessar a prática de cura deve estar disposto a se entregar. Quando chamamos algo de nojento, de sujo, estamos falando de algo que nós produzimos. Muitas vezes não temos o cuidado de procurar uma terra para colocar uma casca de banana. Hoje, as cidades com esse chão de plástico, de asfalto, são vistas como obstáculo para essa devolução. A natureza é o nosso sagrado e, por isso, estabelecemos uma relação mais íntima com ela. Para nós não é moda comermos juntos, enterrar as coisas que não comemos, usarmos as coisas da natureza. Para nós e a própria prática religiosa. Antes de entrar no espaço sagrado ocorre a organização física, para se tomar banho, descansar, acalmar, seja para os afazeres ou por ser simplesmente um lugar onde se sente bem. Nossos corpos são "esponjas" e absorvem as coisas, pois o meu sagrado ajuda a curar o seu sagrado, logo, ao passar por pessoas que precisam desse auxílio, podemos absorver. Cada vez que se isola em um muro ou grade você não está se protegendo, mas se protege nas relações. 